\title{
Pengaruh Iklan Islami Terhadap Minat Beli Calon Konsumen Matahari Dept. Store di Jawa Tengah
}

\author{
Saifudin \\ Institut Agama Islam Negeri Salatiga \\ saifudin@iainsalatiga.ac.id
}

\begin{abstract}
The purpose of this research is to find out the influence of Islamic advertising (Islamic advertising messages, Islamic story illustrations and Muslim advertising stars) Mahatahari Dept. Store against the buying interest of prospective Mahatahari Dept. Store in Central Java. This research was conducted in Central Java Province with a sample size taken as many as 120 respondents with a purposive sampling method. Data was collected by distributing questionnaires using the Likert scale to measure 13 indicators. The analysis technique used is multiple linear regression analysis. The results of the study found that Islamic advertising messages, illustrations of Islamic stories and Muslim advertising stars had a positive and significant effect on consumers' buying interest. Based on the calculation of the coefficient of determination, it can be explained that the simultaneous influence of Islamic advertising message variables, illustrations of Islamic stories and Muslim advertising stars on consumer buying interest. While the partial results of the illustrative variable of Islamic stories and Muslim advertising stars have a positive and significant effect on consumer buying interest, but Islamic advertising message variables have no effect on buying interest.
\end{abstract}

Keywords: Islamic advertising messages, illustrations of Islamic stories, Muslim advertising stars, buying interest

\begin{abstract}
Abstrak
Peneltian ini bertujuan untuk mengetahui pengaruh iklan islami (pesan iklan islami, ilustrasi cerita islami dan bintang iklan muslim) Mahatahari Dept. Store terhadap minat beli calon konsumen Mahatahari Dept. Store di Jawa Tengah. Penelitian dilaksanakan di Provinsi Jawa Tengah dengan mengambil sampel sebanyak 120 orang responden yang dipilih secara purposive sampling. Pengumpulan data dilakukan dengan menyebarkan kuesioner berskala likert untuk mengukur 13 indikator, dengan menggunakan teknik analisis regresi linier berganda. Hasil penelitian menemukan bahwa pesan iklan islami, ilustrasi cerita islami dan bintang iklan muslim memiliki pengaruh positif dan signifikan terhadap minat beli konsumen. Berdasarkan hasil perhitungan koefisien determinasi dapat dijelaskan bahwa pengaruh secara simultan antara variabel pesan iklan islami, ilustrasi cerita islami dan bintang iklan muslim terhadap minat beli konsumen. Sementara hasil secara parsial variabel ilustrasi cerita islami dan bintang iklan muslim memiliki positif dan signifikan terhadap minat beli konsumen, tetapi variabel pesan iklan islami tidak berpengaruh terhadap minat beli.
\end{abstract}

Kata Kunci: pesan iklan islami, ilustrasi cerita islami, bintang iklan muslim, minat beli 


\section{PENDAHULUAN}

Matahari Department Store memiliki perjalanan yang panjang dalam dunia ritel Indonesia. Memulai bisnis ritelnya sejak 24 Oktober 1958 dengan gerai pertamanya hanya berupa toko pakaian anak-anak yang berlokasi di Pasar Baru Jakarta, Matahari kemudian menjadi pionir department store modern di Indonesia pada tahun 1972. Sejak itu Matahari mendeklarasikan dirinya sebagai merek asli nasional dan sampai detik ini mengoperasikan 155 gerai yang tersebar di 74 kota di seluruh Indonesia (www.matahari.co.id), dengan luas ruang hampir satu juta meter persegi dan kini telah mengembangkan bisnisnya dalam dunia online melalui matahari store.com.

Menurut data yang diperoleh dari Top Brand Award fase 2, terdapat beberapa merek Departement Store yang masuk dalam kategori merek dengan market share terbesar seperti dalam tabel berikut:

\section{Tabel 1}

\section{Top Brand Index 2018 Fase 2}

\begin{tabular}{lcc}
\hline \multicolumn{1}{c}{ Merk } & TBI & TOP \\
\hline Matahari & $58,1 \%$ & TOP \\
\hline Ramayana & $21,8 \%$ & TOP \\
\hline Toserba Yogya & $3,4 \%$ & \\
\hline Centro & $2,6 \%$ & \\
\hline \multicolumn{2}{l}{ Sumber : www.topbrand.com $(2018)$}
\end{tabular}

Dengan sederet prestasi yang gemilang ternyata Matahari Departement Store faktanya telah menutup satu unit gerai pada tahun 2018, yang berlokasi di Medan, Sumatera Utara. Langkah itu dilakukan seiring dengan tidak diperolehnya kinerja yang signifikan sepanjang gerai tersebut beroperasi. Tak hanya pertengahan bulan april 2018, sepanjang tahun 2017 lalu Matahari juga tercatat telah menutup sebanyak empat unit gerai (www.katadata.co.id). Chief Financial Officer Matahari Clarissa Joesoep menuturkan penutupan gerai di tahun 2017 lalu disebabkan oleh performa keempat gerai tersebut kurang mumpuni dalam mendongkrak penjualan. Sehingga akhirnya perusahaan memutuskan untuk menutup gerai (www.katadata.co.id). Dengan adanya penutupan gerai terus menerus dikhawatirkan akan menurunkan keuntungan Matahari Departemen Store, sehingga iklan menjadi pesan komunikasi yang sangat penting dalam meningkatkan minat beli konsumen. Mengingat penduduk di Indonesia mayoritas beragama islam maka penelitian tentang pengaruh iklan islami terhadap minat beli penting untuk dilakukan.

Penelitian tentang iklan sudah banyak dilakukan antara lain seperti penelitian Mohammad Esmaeil Ansari dan Seyyed Yaser Ebrahimian Joloudar (2011), Choi and Rifon (2012), Fauzan (2013), Adeyanju Apejoye (2013) G.Radha dan Jija.P (2013), Gunawan dan Dharmayanti (2014), Hemamalini. K.S dan Shree Kala Kurup (2014), Ying Fang Lai et al. (2015), Ali Hassan (2015), Winata (2017), Burhanudin (2017), Herdaningtyas dan Iriani (2017), dan Burhanudin (2017). Namun penelitian sebelumnya hanya fokus pada variabel dan indikator secara umum. Maka dalam hal ini, peneliti mencoba 
menyertakan indikator-indikator islami pada iklan. Disamping itu penelitian sebelumnya memilih responden terbatas pada satu institusi atau satu kabupaten/kota, sedangkan penelitian ini peneliti mencoba mengambil sampel yang lebih luas yaitu se-provinsi Jawa Tengah.

Dengan demikian yang menjadi permasalahan dalam penelitian ini adalah pertama, apakah pesan iklan islami berpengaruh terhadap minat beli calon konsumen yang melihat iklan Matahari Dept. Store di Jawa Tengah. Kedua, apakah ilustrasi cerita islami berpengaruh terhadap minat calon konsumen yang melihat iklan Matahari Dept. Store di Jawa Tengah. Ketiga, apakah bintang iklan muslim berpengaruh terhadap minat beli calon konsumen yang melihat iklan Matahari Dept. Store di Jawa Tengah. Keempat, apakah iklan islami yang terdiri dari pesan iklan islami, ilustrasi cerita islami dan bintang iklan muslim berpengaruh secara bersama-sama terhadap minat beli di Jawa Tengah.

Adapun tujuan penelitian ini adalah: pertama, untuk menjelaskan pengaruh pesan iklan islami terhadap minat beli calon konsumen yang melihat iklan Matahari Dept. Store di Jawa Tengah. Kedua, untuk menjelaskan pengaruh ilustrasi cerita islami terhadap minat calon konsumen yang melihat iklan Matahari Dept. Store di Jawa Tengah. Ketiga, untuk menjelaskan pengaruh bintang iklan muslim terhadap minat beli calon konsumen yang melihat iklan Matahari Dept. Store di Jawa Tengah. Keempat, pengaruh secara bersamasama iklan islami yang terdiri dari pesan iklan islami, ilustrasi cerita islami dan bintang iklan muslim terhadap minat beli di Jawa Tengah.

Penelitian ini memiliki kontribusi bagi para praktisi bisnis ritel syariah agar dapat memperkirakan perilaku calon konsumen. Sedangkan untuk para akademisi, hasil penelitian ini digunakan untuk penelitian selanjutnya dengan mengintegrasikan iklan islami sebagai prediktor behavioral intention pada konsumen muslim. Secara empiris riset ini berguna untuk meningkatkan pemahaman tentang iklan islami dan perilaku calon konsumennya.

\section{KAJIAN LITERATUR \\ Iklan Islami}

Kotler \& Keller (2012:478), menyatakan bahwa iklan adalah : “Any paid form of non personal presentation and promotion of ideas, goods, or services by an identified sponsor", artinya segala bentuk presentasi non-pribadi dan promosi ide, barang, atau layanan berbayar oleh sponsor yang diidentifikasi. Maka periklanan dapat diartikan sebagai setiap bentuk presentasi dan promosi yang dilakukan oleh perusahaan (bersifat non personal) berupa ide, barang atau jasa yang telah ditentukan oleh sponsor.

Iklan juga dapat diartikan sebagai pesan komunikasi yang disebarluaskan kepada calon konsumen untuk memperkenalkan dan menawarkan suatu produk, jasa atau gagasan yang tujuannya mempengaruhi calon konsumen. Iklan memberikan banyak fungsi yaitu informing, persuading, reminding, adding value, dan bantuan untuk upaya lain perusahaan (Shimp, 2003:357). 
Iklan menjadi salah satu bagian terpenting dalam strategi pemasaran. Pemasaran tanpa beriklan bagaikan seseorang mempunyai produk bagus tapi tak pernah ditawarkan pada pembeli (Widyatama, 2007:25).

Jika melihat tujuan iklan, maka iklan mempunyai dua fungsi, yaitu fungsi informatif dan fungsi transformatif (Kotler, 1997:236). Dalam konsep ekonomi syariah, Islam tidak mendukung fungsi informatif sebuah iklan, dengan syarat harus dilandasi oleh sifat shiddiq dan amanah. Sedangkan fungsi transformatif iklan berfungsi untuk mengubah sikap-sikap yang dimiliki konsumen terhadap merek, pola belanja, gaya hidup, teknik-teknik mencapai sukses, dan sebagainya. Dari sisi produk, islam melarang memperdagangkan produk yang haram, sehingga mengubah sikap konsumen terhadap sebuah merek itu boleh saja, asalkan merek tersebut memang benar-benar sesuai dengan citra yang dibangun pemasar (Shiddiq) serta tidak menghalalkan produk yang haram. (Mutaqin, 2013:8).

Dari penjelasan diatas maka iklan islami dalam penelitian ini diartikan sebagai pesan komunikasi yang memiliki konten nilai-nilai keislaman yang disebarluaskan kepada calon konsumen untuk memperkenalkan dan menawarkan suatu produk, jasa atau gagasan.

\section{Pesan Iklan Islami}

Menurut Chandra (2002:170), pesan iklan merupakan sesuatu yang ingin disampaikan kepada calon pelanggan, yaitu berkaitan dengan tiga jenis daya tarik atau unique selling proposition (USP) yang ditawarkan kepada para calon pelanggan, yaitu :

1. Daya tarik rasional (rational appeals)

Daya tarik rasional menekankan manfaat produk, seperti kualitas, harga, nilai atau kinerja produk.

2. Daya tarik emosional (emotional appeals)

Daya tarik emosional memanfaatkan emosi positif atau negatif konsumen. Seperti pesan yang menunjukkan rasa senang, rasa bangga, cinta, rasa sedih, rasa malu, tegang, dan sebagainya. Pesan-pesan tersebut dimanfaatkan dalam rangka memotivasi pembelian.

3. Daya tarik moral (moral appeals)

Daya tarik moral fokus terhadap upaya mendorong konsumen agar mau mendukung atau berpartisipasi dalam kegiatan sosial.

Berdasarkan teori diatas pesan iklan islami dalam penelitian ini dapat diartikan sebagai pesan iklan yang mengandung konten nilai-nilai keislaman serta memiliki daya tarik rasional, emosional dan moral. Menurut Widyatama (2006:63) indikator pesan iklan terdiri dari tingkat kemudahan mengingat pesan iklan dan tingkat pemahaman pesan iklan. Penelitian Hemamalini. K.S dan Shree Kala Kurup (2014), membuktikan bahwa pesan iklan berpengaruh positif dan signifikan terhadap minat beli. Dengan kemudahan mengingat dan memahami pesan iklan yang islami akan memunculkan niat beli calon konsumen. 
Pengaruh Iklan Islami Terhadap Minat Beli Calon Konsumen Matahari Dept. Store di Jawa Tengah

\section{Ilustrasi Cerita Islami}

Menurut Russel (dalam Suyanto, 2005:60) ilustrasi cerita atau yang juga sering disebut storyboard adalah visualisasi untuk iklan televisi yang merupakan rangkaian gambar yang menampilkan alur cerita. Ilustrasi cerita berbentuk narasi yang akan disampaikan kepada calon konsumen. Narasi berasal dari kata Latin narre, yang artinya "membuat tahu". Dengan demikian, narasi berkaitan dengan upaya untuk memberitahu sesuatu atau peristiwa (Suyanto, 2005:60).

Setiap cerita selalu menampilkan peristiwa di dalamnya. Peristiwa dirangkai sedemikian rupa agar rangkaian peristiwa dalam ilustrasi cerita mempunyai makna tertentu (Eriyanto, 2013:15). Dikalangan para ahli sendiri terdapat beberapa pendapat mengenai definisi narasi (Eriyanto, 2013:1)

1. Girard Ganette : Representation of events or of a sequence of events. (Representasi dari sebuah peristiwa atau rangkaian peristiwa-peristiwa).

2. Gerald Prince: The representation of one or more real or fictive events communicated by one, two, or several narator to one, two, or several narratees (Representasi dari satu atau lebih peristiwa nyata atau fiktif yang dikomunikasikan oleh satu, dua, atau beberapa narator untuk satu, dua, atau beberapa naratee)

3. Porter Abbott : Representation of events, consisting of story and narrative discourse, story an events or sequence of events (the actions) and narrative discourse is those events as represented. (Representasi dari peristiwaperistiwa, memasukkan cerita dan wacana naratif, dimana cerita adalah rangkaian peristiwa (tindakan) sedangkan wacana naratif adalah peristiwa yang ditampilkan.

Iklan selalu menawarkan ideologi konsumerisme dan hedonisme. Iklan menawarkan kenikmatan dan keindahan dunia kepada konsumen akan produk yang diiklankan (hedonisme). Ia berusaha menampilkan kekurangankekurangan yang ada pada diri konsumen dalam kehidupannya. Kekurangankekurangan tersebut dapat terpenuhi jika konsumen mengkonsumsi atau memakai produk yang diiklankan. Dalam pandangan ekonomi syariah, sebagai makhluk budaya, manusia akan terus membuat standar-standar tentang apa yang pantas dan tidak pantas dalam pergaulan social (Mutaqin, 2013:8). Proses seperti inilah yang menumbuhkan produsen-produsen berlomba-lomba memenuhi kekurangan manusia dari dinamika standar tersebut. Oleh karena itu, islam menganut prinsip freedom to act, tetapi harus dilandasi oleh tauhid. Sehingga ideologi yang dihembuskan iklan harus dalam batas-batas yang tidak merusak tauhid manusia. Dalam hal ini, konsumen harus ditunjukkan akan kebutuhan hidup dan bukan keinginan hidup yang menggiring kepada pola hidup konsumerisme dan hedonisme. (Mutaqin, 2013:8).

Dari penjelasan diatas maka ilustrasi cerita islami dalam penelitian ini dimaknai sebagai iklan yang memiliki konten narasi kebaikan sesuai ajaran islam, bukan tentang cerita hidup konsumerisme dan hedonisme. Indikator variabel lustrasi cerita adalah tingkat kemenarikan cerita iklan, tingkat 
kemudahan mengingat cerita iklan, dan tingkat kesuksesan jalan cerita iklan (Winata, 2017:5670). Maka ilustrasi cerita islami dari suatu iklan harus dirancang untuk memaksimalkan visualisasi dan alur cerita iklan islami yang menarik, mudah dan jalan cerita yang sukses. Visualisasi dan alur cerita yang unik (misalnya mengandung cerita islami) akan dapat menarik perhatian calon konsumen dan membantu mereka lebih mudah memahami maksud iklan tersebut dan akhirnya berniat melakukan pembelian.

Berdasarkan penelitian Winata membuktikan bahwa ilustrasi cerita berpengaruh positif dan signifikan terhadap minat beli konsumen dan calon konsumen (Winata, 2017:5684). Ilustrasi cerita mempunyai pengaruh terhadap minat beli, mengingat pada tahap awal calon konsumen memiliki motif yang berbeda-beda dalam memilih produk atau jasa. Sudah seharusnya pengiklan melengkapi fungsi dasar iklannya agar dapat meningkatkan kualitas iklan sehingga membedakan iklan tersebut dengan iklan-iklan pada umumnya.

\section{Bintang Iklan Muslim}

Sebuah iklan selalu dibawakan oleh pemeran bintang iklan sebagai subjek yang akan menyampaikan informasi ataupun promosi berupa pesan produk atau jasa. Menurut Shimp bintang iklan adalah pendukung iklan yang mendukung produk yang diiklankan (dalam Faizan, 2013:2). Bintang iklan dapat dipilih dari bintang film, tokoh masyarakat, anak-anak, ataupun tokoh kartun yang mampu mendukung gambaran brand (Kasali, 2004:38). Dalam penelitian ini yang dimaksud dengan bintang iklan muslim adalah pendukung iklan muslim atau muslimah (beragama islam) yang mendukung produk yang diiklankan.

Peran bintang iklan berpengaruh terhadap proses penyampaian pesan, dimana kredibilitas yang dimiliki bintang iklan berupa kemampuan, kecakapan dan daya tarik bintang iklan menjadi fokus para konsumen untuk memunculkan minat pembelian (Shimp dalam Faizan, 2013:3). Kesesuaian antara bintang iklan dengan produk atau jasa yang diiklankan juga seringkali menjadi salah satu kunci efektivitas dari sebuah bintang iklan.

Menurut Biswas et al., (dalam Wijaya, 2015:40), kecocokan atau kongruensi bintang iklan mengacu pada tingkat kesesuaian citra diri seorang bintang iklan dengan produk yang dibawakan. Bintang iklan muslim tentu akan sesuai dengan produk/jasa yang diperuntukkan bagi orang yang beragama islam. Indikator variabel bintang iklan menurut Kasali yaitu tingkat kemenarikan bintang iklan, tingkat kesesuaian bintang iklan dengan produk, dan tingkat minat beli karena bintang iklan. (Kasali, 2004:38).

Penelitian Biswas et al. (dalam Wijaya, 2015:40), menemukan bahwa bintang iklan yang memiliki kesesuaian tinggi pada produk yang diiklankannya akan memiliki respon konsumen yang lebih positif. Seorang bintang iklan muslim yang menarik dan sesuai dengan produk/jasa yang diiklankan dapat mempengaruhi minat beli calon konsumen. 
Pengaruh Iklan Islami Terhadap Minat Beli Calon Konsumen Matahari Dept.

Store di Jawa Tengah

\section{Minat Beli}

Dalam strategi pemasaran perilaku konsumen menjadi perhatian yang serius bagi produsen atau penyedia jasa, salah satunya adalah niat pembelian. Niat pembelian diartikan sebagai keadaan di mana pelanggan merasa senang untuk melakukan transaksi dengan produsen atau penyedia jasa. Menurut Dodds, Monroe, dan Grewal (dalam Rizwan et al., 2014:3) minat beli adalah ketika seorang pelanggan kemungkinan besar mencoba untuk membeli beberapa produk atau layanan.

Tahapan-tahapan konsumen dalam menentukan minat belinya atau dorongan untuk melakukan pembelian terhadap produk dan jasa yang ditawarkan, dapat menggunakan indikator model AIDA yang dikembangkan oleh Kotler (2012:568), yaitu:

\section{Attention}

Pada tahap awal ini konsumen berusaha menilai suatu produk atau jasa yang sesuai dengan kebutuhannya, selain itu calon konsumen juga berusaha mempelajari produk atau jasa yang telah ditawarkan.

2. Interest

Pada tahap kedua ini calon konsumen mulai tertarik pada produk atau jasa yang ditawarkan dan membelinya, setelah mereka memperoleh informasi yang lebih detail tentang produk atau jasa yang telah ditawarkan.

3. Desire

Pada tahap ini calon konsumen memikirkan dan berdiskusi tentang produk ataupun jasa yang ditawarkan, karena hasrat dan keinginan membeli sudah mulai muncul. Calon konsumen juga mulai berminat terhadap produk atau jasa yang ditawarkan, ditandai dengan munculnya minat yang kuat dari calon konsumen untuk mencoba dan membeli produk atau jasa yang ditawarkan.

4. Action

Pada tahap ini calon pelanggan telah mempunyai kemantapan yang tinggi untuk membeli atau menggunakan produk atau jasa yang ditawarkan.

\section{Hubungan Pesan Iklan, Ilustrasi Cerita, Bintang Iklan, dan Minat Beli}

Pesan iklan yang disampaikan oleh pengiklan memberikan efek serius terhadap minat beli calon konsumennya. Penelitian Burhanudin (2017) yang berjudul pengaruh iklan traveloka di televisi terhadap minat beli konsumen membuktikan bahwa iklan Traveloka di televisi memiliki dampak positif yang signifikan terhadap minat beli konsumen. Begitu juga penelitian Gunawan dan Dharmayanti (2014), Herdaningtyas dan Iriani (2017), Winata (2017), menyimpulkan bahwa iklan berpengaruh terhadap minat beli.

Pesan iklan yang mampu diterima baik oleh calon konsumen selanjutnya akan menimbulkan niat melakukan pembelian. Penelitian Hemamalini. K.S dan Shree Kala Kurup (2014), Ying Fang Lai et al. (2015), Burhanudin (2017), dan Winata (2017) membuktikan bahwa pesan iklan berpengaruh positif dan signifikan terhadap minat beli. 
Tidak hanya pesan iklan, ilustrasi cerita yang menarik juga akan merangsang calon konsumen untuk memiliki niat membeli sebuah produk atau jasa. Penelitian Mohammad Esmaeil Ansari dan Seyyed Yaser Ebrahimian Joloudar (2011), Ali Hassan (2015), dan Winata (2017) membuktikan bahwa ilustrasi cerita berpengaruh positif dan signifikan terhadap minat beli konsumen.

Pesan iklan dan ilustrasi cerita yang menarik tanpa didukung bintang iklan yang sesuai justru menjadi bumerang bagi perusahaan. Bintang iklan yang menarik dan sesuai dengan produk yang diiklankan akan menumbuhkan niat beli calon konsumen. Penelitian Choi and Rifon (2012), Fauzan (2013) membuktikan bintang iklan berpengaruh positif dan signifikan terhadap proses keputusan pembelian. Menurut penelitian Adeyanju Apejoye (2013) G.Radha dan Jija.P (2013), dan Winata (2017) membuktikan bahwa bintang iklan berpengaruh terhadap minat beli konsumen.

\section{Kerangka Pemikiran}

Berdasarkan uraian diatas maka bisa dibuat kerangka pikir dalam penelitian ini sebagai berikut:

\section{Gambar 1 \\ Kerangka Pikir}

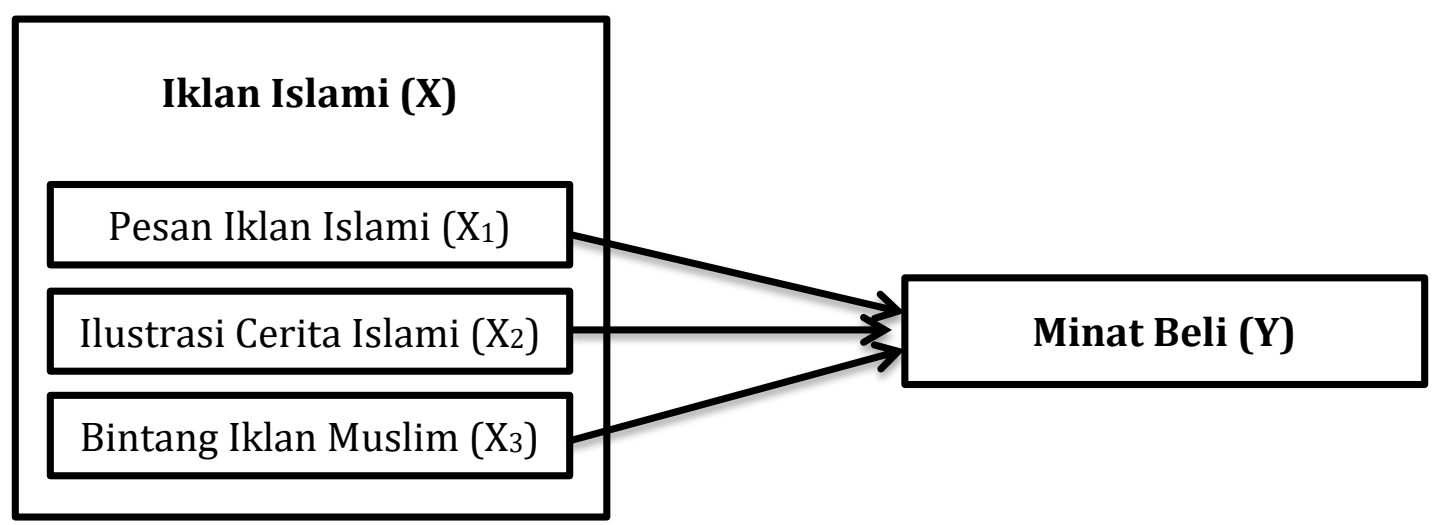

Hipotesis

Berdasarkan kerangka pemikiran diatas, maka dapat dirumuskan hipotesisnya sebagai berikut :

Ha1: Pesan iklan islami berpengaruh terhadap minat beli calon konsumen yang melihat iklan Matahari Dept. Store.

Ha2: Ilustrasi cerita islami berpengaruh terhadap minat calon konsumen yang melihat iklan Matahari Dept. Store.

Ha3: Bintang iklan muslim berpengaruh terhadap minat beli calon konsumen yang melihat iklan Matahari Dept. Store.

Ha4: Pesan iklan islami, ilustrasi cerita islami dan bintang iklan muslim berpengaruh secara bersama-sama terhadap minat beli.

\section{METODE PENELITIAN}

Penelitian ini menggunakan pendekatan kuantitatif dengan tujuan untuk menjelaskan pengaruh satu atau lebih variabel bebas terhadap variabel 
Pengaruh Iklan Islami Terhadap Minat Beli Calon Konsumen Matahari Dept. Store di Jawa Tengah

terikat. Populasi penelitian ini adalah penduduk di Jawa Tengah. Sampel diperoleh dengan purposive sampling yang mana kriteria responden adalah orang yang pernah menonton iklan Matahari Dept. Store selama bulan Ramadhan 1440 H/2019. Adapun kuesioner yang disebarkan berjumlah 130 kuesioner, namun hanya 120 kuesioner yang diolah dalam penelitian ini karena 10 kuesioner tidak terisi lengkap. Kuesioner diedarkan dari tanggal 6 Mei sampai 2 Juni 2019. Metode analisis yang dipergunakan dalam penelitian ini ialah analisis regresi karena untuk melihat hubungan antara variable bebas dan variabel terikat.

\section{Definisi Operasional Variabel}

Ada dua variabel dalam penelitian ini yaitu variabel independen (X) dan variabel dependen (Y), sedangkan untuk memperjelas dari pengertian variabel dalam penelitian ini, maka definisi opersionalnya sebagai berikut :

Tabel 2

Indikator Variabel

\begin{tabular}{|c|c|c|}
\hline Variabel & Indikator & Sumber \\
\hline Pesan Iklan Islami (X1) & $\begin{array}{l}\text { 1. Tingkat kemudahan } \\
\text { mengingat pesan iklan } \\
\text { islami } \\
\text { 2. Tingkat pemahaman } \\
\text { pesan iklan islami }\end{array}$ & $\begin{array}{l}\text { Widyatama } \\
(2006: 63)\end{array}$ \\
\hline Ilustrasi Cerita Islami (X2) & $\begin{array}{l}\text { 1. Tingkat kemenarikan } \\
\text { cerita iklan islami } \\
\text { 2. Tingkat kemudahan } \\
\text { mengingat cerita iklan } \\
\text { islami } \\
\text { 3. Tingkat kesuksesan jalan } \\
\text { cerita iklan islami }\end{array}$ & $\begin{array}{l}\text { Winata } \\
(2017: 5669)\end{array}$ \\
\hline Bintang Iklan Muslim (X3) & $\begin{array}{l}\text { 1. Tingkat kemenarikan } \\
\text { bintang iklan muslim } \\
\text { 2. Tingkat kesesuaian } \\
\text { bintang iklan dengan } \\
\text { produk } \\
\text { 3. Tingkat minat beli } \\
\text { karena bintang iklan } \\
\text { muslim }\end{array}$ & $\begin{array}{l}\text { Kasali } \\
(2004: 38)\end{array}$ \\
\hline Minat Beli (Y) & $\begin{array}{ll}\text { 1. } & \text { Attention } \\
\text { 2. } & \text { Interest } \\
\text { 3. } & \text { Desire } \\
\text { 4. } & \text { Action }\end{array}$ & $\begin{array}{l}\text { Kotler } \\
(2012: 568)\end{array}$ \\
\hline
\end{tabular}




\section{Metode Analisis}

Instrumen dalam penelitian ini diuji menggunakan uji validitas dan reliabilitas.

\section{Uji validitas}

Uji validitas ini untuk mengetahui valid atau tidaknya item kuisioner. Uji validitas dilakukan dengan membandingkan nilai korelasi (corrected itemtotal correlation) atau $r$ hitung dengan nilai $r$ tabel. Jika $r$ hitung memiliki nilai lebih besar dari nilai $r$ tabel maka isntrumen dianggap valid (Machali, 2015:157). Berdasarkan pengujian validitas dari semua indikator pertanyaan dalam penelitian ini dinyatakan valid dengan derajat kebebasan $\mathrm{df}=\mathrm{n}-2$ atau $\mathrm{df}=120-2$ adalah 118 , dengan taraf signifikansi 0,05 sehingga hasil $r$ tabelnya 0.179 .

\section{Uji Reliabilitas}

Untuk mengetahui seberapa besar hasil pengukuran tetap sama apabila dilakukan pengukuran dua kali atau lebih terhadap gejala yang sama dengan alat pengukur yang sama maka dilakukan uji reliabilitas. Reliability Statistics menunjukkan hasil perhitungan reliabilitas data dengan menggunakan metode alpha Cronbach (Machali, 2015:158).

1. Regresi linier berganda, rumus yang digunakan adalah :

$\mathrm{Y}=\mathrm{a}+\mathrm{b} \mathrm{X}_{1}+\mathrm{b}_{2} \mathrm{X}_{2}+\mathrm{b}_{3} \mathrm{X}_{3}+\ldots . . \mathrm{b}_{\mathrm{n}} \mathrm{X}_{\mathrm{n}}+\mathrm{e}$

Keterangan:

$\mathrm{X}_{1}$ : Pesan Iklan Islami

$\mathrm{X}_{2}$ : Ilustrasi Cerita Islami

$\mathrm{X}_{3}$ : Bintang Iklan Muslim

Y : Minat Beli

E : Standart Eror

2. Analisis koefisien Determinasi

Nilai korelasi (R) adalah nilai secara simultan antara variabel pesan iklan islami (X1), ilustrasi cerita islami (X2), dan bintang iklan muslim (X3) terhadap minat beli (Y). Porsentase $\mathrm{R}$ Square (korelasi koefisien) menunjukkan kontribusi yang disumbangkan X1, X2, dan X3 kepada Y (Machali, 2015:150). Koefisien determinasi ini berfungsi untuk menentukan besarnya variasi variabel dependen yang dapat dijelaskan oleh variabel independen.

Nilai $\mathrm{R}^{2}$ digunakan rumus sebagai berikut:

$\mathrm{R}^{2}=\frac{b_{1} \sum x_{1} y+b_{2} \sum x_{2} y+b_{3} \sum x_{3} y}{\sum y^{2}}$ dimana $0 \leq \mathrm{R}^{2} \leq 1$

Diketahui:

$\mathrm{R}^{2}=$ Koefisien determinasi 
Pengaruh Iklan Islami Terhadap Minat Beli Calon Konsumen Matahari Dept. Store di Jawa Tengah

\section{Uji Hipotesis}

Uji hipotesis yang digunakan dalam penelitian ini yaitu uji f dan uji t.

\section{Hasil Uji t}

Untuk mengetahui apakah ada pengaruh secara sendiri-sendiri (parsial) antara variabel independen dan variabel dependen diperlukan uji t. Tingkat signifikan terhadap pengujian ini 0,05 dimana, jika anggota probabilitas signifikan <0,05 maka Ho di tolak dan Ha diterima, dan sebaliknya jika angka probabilitas $>0,05$ maka Ho diterima dan Ha ditolak.

\section{Hasil Uji F}

Uji $\mathrm{F}$ digunakan untuk menguji tingkat signifikansi dari pengaruh variabel independen secara bersama-sama dengan variabel dependen. Perbandingan $F_{-}$hitung dan $F_{-}$tabel serta sig $<0,05$ dan $\alpha$ : F_hitung $>$ F_tabel maka H0 ditolak dan Ha diterima (Machali, 2015:150).

\section{PEMBAHASAN}

Dalam penelitian ini berdasarkan pengujian validitas dari seluruh indikator pertanyaan dinyatakan valid dengan derajat kebebasan $\mathrm{df}=\mathrm{n}-2$ atau $\mathrm{df}=120$ 2 adalah 118, dengan taraf signifikansi 0,05 sehingga hasilnya $r$ table 0.179 . Uji validitas semua item kuisioner atau pertanyaan memiliki $r$ hitung $>r$ table dan bernilai positif, maka item pertanyaan dalam penelitian ini bersifat valid dan layak (Machali, 2015:159). Berdasarkan uji reliabilitas dari semua indikator pertanyaan dalam penelitian ini dinyatakan reliable karena hasilnya 0.878 artinya melebihi nilai kritis 0,6 sehingga bisa dikatakan hasil pengukuran tetap konsisten.

\section{Analisis Regresi Berganda}

Model analisis regresi berganda ini dipakai untuk mengetahui peran variabel independen (pesan iklan islami, ilustrasi cerita islami, dan bintang iklan muslim) terhadap variabel dependen (minat beli). Hasil pengolahan data menggunakan program SPSS sebagai berikut:

\section{Tabel 3}

\section{Coefficients ${ }^{\mathbf{a}}$}

\begin{tabular}{lrrrrrr}
\hline & \multicolumn{2}{c}{$\begin{array}{c}\text { Unstandardized } \\
\text { Coefficients }\end{array}$} & \multicolumn{2}{c}{$\begin{array}{c}\text { Standardized } \\
\text { Coefficients }\end{array}$} & & \\
\cline { 2 - 5 } Model & B & Std. Error & Beta & T & \multicolumn{1}{c}{ Sig. } \\
\hline 1 (Constant) & .311 & .393 & & .790 & .431 \\
\hline XPI & .161 & .109 & .135 & 1.488 & .140 \\
\hline XIC & .208 & .121 & .178 & 1.720 & .038 \\
\hline XBI & .452 & .108 & .387 & 4.195 & .000 \\
\hline
\end{tabular}


Coefficients $^{\mathbf{a}}$

\begin{tabular}{lrrrrrr}
\hline & \multicolumn{2}{c}{$\begin{array}{c}\text { Unstandardized } \\
\text { Coefficients }\end{array}$} & \multicolumn{2}{c}{$\begin{array}{c}\text { Standardized } \\
\text { Coefficients }\end{array}$} & & \\
\cline { 2 - 5 } Model & B & Std. Error & Beta & & T & \multicolumn{1}{c}{ Sig. } \\
\hline 1 (Constant) & .311 & .393 & & .790 & .431 \\
\hline XPI & .161 & .109 & .135 & 1.488 & .140 \\
\hline XIC & .208 & .121 & .178 & 1.720 & .038 \\
\hline XBI & .452 & .108 & .387 & 4.195 & .000 \\
\hline
\end{tabular}

Sumber: data diolah 2019

1. Variabel pesan iklan islami ( $\left.\mathrm{X}_{1}\right)$ terhadap minat beli.

Nilai koefisien iklan islami $\left(\mathrm{X}_{1}\right)$ senilai 0,161 , menggambarkan bahwa pesan iklan islami mempunyai nilai positif yang berarti pesan iklan islami mempunyai peran positif terhadap minat beli dan apabila pesan iklan islami ditingkatkan satu satuan sehingga akan berperan penigkatan minat beli 0,161 .

2. Variabel ilustrasi cerita islami $\left(\mathrm{X}_{2}\right)$ terhadap minat beli.

Nilai koefisien sebesar 0,208, menggambarkan bahwa ilustrasi cerita islami mempunyai nilai positif artinya ilustrasi cerita islami mempunyai peran terhadap minat beli dan apabila ilustrasi cerita islami ditingkatkan satu satuan sehingga akan berperan juga peningkatan minat beli senilai 0,208 .

3. Variabel bintang iklan muslim (X3) terhadap minat beli.

Nilai koefisien sebesar 0,452, menggambarkan bahwa bintang iklan muslim mempunyai nilai positif artinya bintang iklan muslim mempunyai peran terhadap minat beli dan apabila bintang iklan muslim ditingkatkan satu satuan sehingga akan berperan juga peningkatan minat beli senilai 0,452 .

\section{Koefisien Determinasi}

Kegunaan koefisien determinasi untuk mengetahui seberapa besar variasi variabel dependen minat beli (Y) yang dapat di prediksikan oleh variabel independen yaitu pesan iklan islami (X1), ilustrasi cerita islami (X2), dan bintang iklan muslim (X3), secara simultan.

Tabel 4

Model Summaryb

\begin{tabular}{ccccc}
\hline Model & R & R Square & $\begin{array}{c}\text { Adjusted R } \\
\text { Square }\end{array}$ & $\begin{array}{c}\text { Std. Error of the } \\
\text { Estimate }\end{array}$ \\
\hline 1 & $.736^{\mathrm{a}}$ & .542 & .527 & .725 \\
\hline
\end{tabular}

Sumber: data diolah 2019 
Pengaruh Iklan Islami Terhadap Minat Beli Calon Konsumen Matahari Dept.

Store di Jawa Tengah

Berdasarkan table 4 dijelaskan bahwa koefisiesn determinasi atau R Square senilai 0,542 yang berarti bahwa minat beli (variabel dependen) dapat dijelaskan oleh pesan iklan islami, ilustrasi cerita islami, dan bintang iklan Muslim (variabel Independen) senilai 54,2\% dan sisanya 45,8\% diperankan oleh faktor-faktor lain yang tidak diamati oleh peneliti, seperti life style, pendapatan, harga, kualitas produk, dan sebagainya.

\section{Pengujian Hipotesis}

Menurut Ghozali (2011:143) hipotesis adalah berkaitan dengan ada tidaknya peran yang signifikan dari pesan iklan islami, ilustrasi cerita islami, dan bintang iklan muslim terhadap minat beli baik secara sendiri-sendiri maupun secara bersama-sama.

\section{Uji t}

Berdasarkan hasil penghitungan table 1 di atas dapat diterangkan bahwa analisis uji t untuk pesan iklan islami (X1) didapatkan hasil nilai t hitung $1.488<\mathrm{t}$ table 1,657 dan atau 0,140 > 0,05 maka Ho diterima dan Ha ditolak, yang berarti tidak ada peran positif dan signifikan antara pesan iklan islami dengan minat beli calon konsumen Matahari Dept. Store. Ilustrasi cerita islami (X2) didapat hasil t hitung senilai 1,720 sehingga t hitung 1,720 >t table 1,657 dan atau 0,038<0,05, maka Ho ditolak dan Ha diterima, yang berarti ada peran positif dan signfikan antara ilustrasi cerita islami dengan minat beli calon konsumen Matahari Dept. Store. Sedangkan bintang iklan muslim (X3) didapat hasil $t$ hitung senilai 4,195 sehingga t hitung 4,195 >t table 1,657 dan atau 0,000<0,05, maka Ho ditolak dan Ha diterima, yang berarti ada peran positif dan signfikan antara bintang iklan muslim dengan minat beli calon konsumen Matahari Dept. Store.

\section{Uji F}

Uji $\mathrm{F}$ adalah perbandingan $\mathrm{F}_{-}$hitung dan $\mathrm{F}_{-}$tabel serta sig $<0,05$ dan $\alpha$ : F_hitung > F_tabel maka H0 ditolak dan Ha diterima (Machali, 2015:150), maka variabel pesan iklan islami, ilustrasi cerita islami, dan bintang iklan muslim (variabel Independen) secara bersama-sama berperan signifikan terhadap minat beli (variabel dependen).

Tabel 5

ANOVA $^{b}$

\begin{tabular}{llrrrrr}
\hline \multirow{2}{*}{ Model } & \multicolumn{1}{c}{$\begin{array}{c}\text { Sum of } \\
\text { Squares }\end{array}$} & df & Mean Square & F & \multirow{2}{*}{ Sig. } \\
\hline 1 & Regression & 31.699 & 3 & 10.566 & 20.129 & $.000^{\text {a }}$ \\
& Residual & 60.893 & 116 & .525 & & \\
Total & 92.592 & 119 & & & \\
\hline
\end{tabular}

Sumber: data diolah 2019 
Berdasarkan hitungan secara bersama-sama didapatkan hasil uji $\mathrm{F}$ hitung senilai 20,129, dan untuk nilai $\mathrm{F}$ table pada tingkat signifikan 0,05 dengan $\mathrm{F}$ table (k; n-k)atau 3; 120-3=117, maka diperoleh hasil untuk $\mathrm{F}$ table senilai 2,65 dan signifikan $0,00<0,05$. Demikian dapat disimpulkan bahwa F hitung $>\mathrm{F}$ table yang berarti bahwa variabel pesan iklan islami, ilustrasi cerita islami, dan bintang iklan muslim secara serempak berperan terhadap variable minat beli calon konsumen Matahari Dept. Store.

\section{Pengaruh Pesan Iklan Islami Terhadap Minat Beli}

Berdasarkan hasil penelitian ini membuktikan bahwa pesan iklan islami berperan secara positif tetapi tidak signifikan terhadap minat beli, karena dilihat dari uji t menunjukkan diketahui nilai t table 1,657, sehingga t hitung $1.488<$ t table 1,657 dan atau 0,140 > 0,05 maka Ho diterima dan Ha ditolak. Artinya pesan iklan islami memang perlu diperhatikan oleh manajemen untuk mendapatkan minat beli dari calon konsumen. Secara umum responden mengatakan dari item pertanyaan tentang pesan iklan islami ratarata menjawab netral. Pesan iklan islami pada iklan Matahari Dept. Store belum dapat mempengaruhi minat beli calon konsumennya karena tingkat kemudahan mengingat pesan iklan yang disampaikan kurang mendapat respon positif dari calon konsumen. Selain itu tingkat pemahaman pesan iklan Matahari Dept. Store dimata konsumen masih membutuhkan pemahaman yang berulang-ulang, sehingga bagi calon konsumen yang melihat kurang dari tiga kali akan kurang memahami pesan yang disampaikan dalam iklan.

Hasil penelitian ini menolak penelitian Winata (2017) yang berjudul pengaruh iklan pada media televisi terhadap minat beli (studi pada calon konsumen bukalapak.com di kota Denpasar), begitu juga penelitian Hemamalini. K.S dan Shree Kala Kurup (2014), Ying Fang Lai et al. (2015), dan Burhanudin (2017) membuktikan bahwa pesan iklan berpengaruh positif dan signifikan terhadap minat beli. Pesan iklan yang mampu diterima baik oleh calon konsumen selanjutnya akan menimbulkan niat melakukan pembelian.

\section{Pengaruh Ilustrasi Cerita Islami Terhadap Minat Beli}

Berdasarkan hasil penelitian ini membuktikan bahwa ilustrasi cerita islami berperan secara positif dan signifikan terhadap minat beli, karena dilihat dari uji t diketahui nilai t table 1,720 sehingga t hitung 1,720 > t table 1,657 dan atau 0,038 $<0,05$ maka Ho ditolak dan Ha diterima. Artinya ilustrasi cerita islami memang perlu diperhatikan oleh manajemen untuk mendapatkan minat beli dari calon konsumen. Secara umum responden mengatakan dari item pertanyaan tentang ilustrasi cerita islami rata-rata menjawab baik. Ilustrasi cerita islami pada iklan Matahari Dept. Store dapat mempengaruhi minat beli calon konsumennya karena tingkat kemenarikan cerita iklan, tingkat kemudahan mengingat cerita iklan tingkat kesuksesan jalan cerita iklan islami sehingga mendapat respon positif dari calon konsumennya. 
Hasil penelitian ini mendukung penelitian Mohammad Esmaeil Ansari dan Seyyed Yaser Ebrahimian Joloudar (2011) yang berjudul an investigation of TV advertisement effects on customers purchasing and their satisfaction yang membuktikan bahwa ilustrasi cerita berpengaruh positif dan signifikan terhadap minat beli konsumen, begitu pula sesuai dengan penelitian Ali Hassan (2015), dan Winata (2017). Ilustrasi cerita islami yang menarik akan merangsang calon konsumen untuk memiliki niat membeli sebuah produk atau jasa.

\section{Pengaruh Bintang Iklan Muslim Terhadap Minat Beli}

Berdasarkan hasil penelitian ini membuktikan bahwa bintang iklan muslim berperan secara positif dan signifikan terhadap minat beli, karena dilihat dari uji t diketahui nilai $t$ table 4,195 sehingga $t$ hitung 4,195 > t table 1,657 dan atau signifikan pada 0,000 < 0,05 maka Ho ditolak dan Ha diterima. Artinya bintang iklan muslim memang perlu diperhatikan oleh manajemen untuk mendapatkan minat beli dari calon konsumen. Secara umum responden mengatakan dari item pertanyaan tentang bintang iklan muslim rata-rata menjawab baik. Bintang iklan muslim pada iklan Matahari Dept. Store dapat mempengaruhi minat beli calon konsumennya karena tingkat kemenarikan bintang iklan muslim, tingkat kesesuaian bintang iklan muslim dengan produk yang diiklankan, dan tingkat minat beli calon konsumen karena bintang iklan muslim tersebut.

Hasil penelitian ini mendukung penelitian Adeyanju Apejoye (2013) yang berjudul influence of celebrity endorsement of advertisement on students' purchase intention yang membuktikan bintang iklan berpengaruh terhadap minat beli konsumen, begitu pula penelitian Choi and Rifon (2012), Fauzan (2013),G.Radha dan Jija.P (2013), dan Winata (2017). Bintang iklan muslim yang menarik dan sesuai dengan produk yang diiklankan akan menumbuhkan niat beli calon konsumen.

\section{SIMPULAN}

Hasil pembahasan dari analisis data yang telah diolah selanjutnya dapat ditarik beberapa intisari dari keseluruhan hasil penelitian yaitu:

1. Tidak terdapat pengaruh variabel pesan iklan islami terhadap minat beli calon konsumen Matahari Dept. Store. Hal ini berdasarkan pengujian hasil uji $\mathrm{t}$ dengan nilai $\mathrm{t}$ hitung $1.488<\mathrm{t}$ table 1,657 dengan nilai signifikansi 0,140>0,05.

2. Terdapat pengaruh positif dan signifikan variabel ilustrasi cerita islami terhadap minat beli calon konsumen Matahari Dept. Store. Hal ini berdasarkan hasil uji t dengan nilai t hitung 1,720 > t table 1,657, denga nilai signifikansi sebesar 0,038.

3. Terdapat pengaruh positif dan signifikan variabel bintang iklan muslim terhadap minat beli calon konsumen Matahari Dept. Store. Hal ini berdasarkan hasil uji t dengan nilai t hitung 4,195 > t table 1,657, denga nilai signifikansi sebesar 0,000. 
4. Terdapat peran positif dan signifikan variabel pesan iklan islami, ilustrasi cerita islami, dan bintang iklan muslim secara serempak terhadap minat beli calon konsumen Matahari Dept. Store. Hal ini dibuktikan berlandaskan hasil uji koefisien determinasi yang dilihat dari nilai R Square senilai 0,542. Hal tersebut berarti peran variabel budaya organisasi, dan komitmen organisasi terhadap variabel kinerja karyawan senilai senilai $54,2 \%$ sedangkan selisihnya yaitu $45,8 \%$ dipengaruhi oleh variabel lain yang tidak diteliti.

5. Berdasarkan hasil perhitungan uji t bahwa variabel yang paling berperan dengan minat beli calon konsumen Matahari Dept. Store adalah bintang iklan muslim, hal ini disebabkan karena bintang iklan muslim memiliki t hitung paling besar yaitu 4,195, yang memiliki nilai signifikan si 0,000 dimana semakin kecil nilai signifikansi maka semakin tinggi penerapannya terhadap minat beli calon konsumen Matahari Dept. Store. Dari hasil penelitian ini rekomendasi dibuat untuk: pertama, para akademisi, peneliti selanjutnya diharapkan mengembangkan model penelitian di bidang pemasaran syariah yang menggunakan variabel-variabel perikalanan islami dan minat beli calon konsumen. Kedua, manajer perusahaan ritel sebaiknya membuat iklannya dengan memasukkan nilai-nilai keislaman untuk memperoleh pasar konsumen muslim di Indonesia. Ketiga untuk pemerintah melalui Komisi Penyiaran Indonesia diharapkan memfilter iklan-iklan yang tidak sesuai dengan nilai-nilai ke-Indonesiaan dan memberikan penghargaan kepada perusahaan yang kreatif membuat iklan dengan konten-konten kebaikan.

\section{DAFTAR PUSTAKA}

Ansari, M. E., dan Seyyed, Y. E. J. (2011). An Investigation of TV Advertisement Effects on Customers Purchasing and Their Satisfaction. International Journal of Marketing Studies, Vol. 3(5). 175181.

Apejoye, Adeyanju. (2013). Influence of Celebrity Endorsement of Advertisement on Students' Purchase Intention. Journal Mass Communicat Journalism, Vol. 3(3). 2-7.

Biswas, D., A. Biswas, and N. Das. (2006). The differential effects of celebrity and expert endorsements on consumer risk perceptions. the role of consumer knowledge, perceived congruency, and product technology orientation. Journal of Advertising. Vol. 35(2). 17-31.

Burhanudin, R. (2017). Pengaruh Iklan Traveloka Di Televisi Terhadap Minat Beli Konsumen. e-Proceeding of Management Vol. 4 (2). 1453-1459.

Chandra, Gregorious. (2002). Strategi dan Program Pemasaran. Edisi Pertama. Yogyakarta: Andi. 
Pengaruh Iklan Islami Terhadap Minat Beli Calon Konsumen Matahari Dept. Store di Jawa Tengah

Choi, SM., and NJ. Rifon. (2012). It Is a Match: The impact of congruence between celebrity image and consumer ideal self on endorsement effectiveness. Psychology and Marketing. Vol. 29(9). 639-650.

Eriyanto. (2013). Analisis Isi Untuk Penelitian Ilmu Komunikasi dan Ilmu sosial Lainnya. Jakarta: Kencana Prenada Media Group.

Faizan, Aklis. (2013). Pengaruh kreatifitas iklan dan endorser terhadap proses keputusan pembelian konsumen mie sedaap. Management Analysis Journal. Vol. 3 (2). 1-8.

Ghozali Imam. (2011). Aplikasi analisis Multivariate dengan program IBM. SPSS 19 edisi 5. Semarang: Universitas Diponegoro.

Gunawan, F. A. \& Dharmayanti, D. (2014). Analisis Pengaruh Iklan Televisi dan Endorser terhadap Purchase Intention Pond's Men dengan Brand Awareness sebagai Variabel Intervening. Jurnal Manajemen Pemasaran Petra. Vol. 2 (1). 1-14.

Hassan, Ali. (2015). Effects Of TV Advertisement On Consumer Buying Behaviour:A Comparative Study of Rural-Urban And Male-Female Consumers. International Journal of Innovation and Applied Studies, Vol. 11(3). 608-614.

Herdaningtyas, G. \& Iriani, F. (2017). Pengaruh Iklan dan Penggunaan Selebritas dalam Iklan terhadap Minat Beli Produk Melalui Kesadaran Merek sebagai Variabel Intervening. Prosiding Seminar Nasional Ekonomi dan Bisnis (SNEBIS), Fakultas Ekonomi, Universitas Krisnadwipayana.

https://katadata.co.id/berita/2018/04/27/kinerja-kurang-mumpunimatahari-department-store-kembali-tutup-gerai.

http://www.matahari.co.id/en/about

https://www.topbrand-award.com/top-brandindex/?tbi_index=Top\%20Brand\&tbi_year $=2018$

Kotler, Philip dan Keller, Kevin Lane. (2012). Marketing management. (14th ed). New Jersey : Pearson.

Kotler, P. (1997). Marketing Esentials, Terj. Herujati Purwoto. Jakarta: Erlangga.

Machali, Imam. (2015). Statistik itu Mudah: Menggunakan SPSS sebagai Alat Bantu Statistik. Yogyakarta: Lembaga Ladang Kata.

Mutaqin, A. (2013). Konsep Periklanan Dalam Ekonomi Islam. Jurnal Cahaya Aktiva, Vol. 3 (1). 1-10.

Radha, G., dan Jija, P. (2013). Influence of Celebrity Endorsement on the Consumer's Purchase Decision. International Journal of HOD, School of Communication, G.R. Damodaran College of Science, Coimbatore, Vol. 3(1). 20-33.

Rizwan, Muhammad. Qayyum, Mudasser. Qadeer, Waqas. Javed, M. (2014). The Impact On Branded Product On Consumer Purchase Intentions. Journal of Public Administration and Governance. Vol. 4 (3). 57-74. 
Shimp, Terence A. (2003). Periklanan Promosi Aspek Tambahan Komunikasi Terpadu Dialihbahasakan oleh Sahrial dan Anikasari. Jilid 1. Edisi ke-5. Jakarta: Erlangga.

Suyanto. (2004). Analisis \& Desain: Aplikasi Multimedia untuk Pemasaran. Yogyakarta: Penerbit Andi.

Widyatama, Rendra. (2007). Pengantar Periklanan. Yogyakarta: Pustaka Book Publisher.

Wijaya, Peter. (2015). Pengaruh Pesan Iklan, Keterlibatan Iklan, Kredibilitas, dan Kecocokan Endorser pada Minat Beli melalui Sikap Konsumen. Jurnal Siasat Bisnis. Vol. 19(1). 36-50.

Winata, A. dan Nurcahya. (2017). Pengaruh Iklan Pada Media Televisi Terhadap Minat Beli (Studi Pada Calon Konsumen Bukalapak.com di Kota Denpasar). E-jurnal Manajemen Unud Vol. 6 (10). 5560-5692. 